\title{
RANCANG BANGUN SISTEM INFORMASI ADMINISTRASI PENJUALAN BERBASIS WEB DENGAN PHP DAN MYSQL PADA TOKO ROYALTI
}

\author{
SRI MULYATI ${ }^{1)}, \&$ ADITYA CHANDRA ${ }^{2)}$ \\ 1),2), Program Studi Informatika \\ Fakultas Teknik Universitas Muhammadiyah Tangerang \\ Jl. Perintis Kemerdekaan 1/33 Cikokol Kota Tangerang \\ E-mail:sri.mulyati@umt.ac.id ${ }^{l)}$
}

\begin{abstract}
ABSTRAK
Kemajuan teknologi yang mengalami perkembangan yang pesat memiliki dampak bagi hampir semua aspek kehidupan. Seiring dengan perkembangan tersebut, hampir semua perusahaan maupun organisasi terus mengikuti perkembangan dan mengantisipasi serta mengatasi tantangan kemajuan tersebut. Sehingga banyak yang memanfaatkan kecanggihan teknologi contohnya dalam bidang administrasi. Pada Toko Royalti sistem administrasi penjualannya nya masih secara manual, oleh karena itu dibutuhkan suatu sistem aplikasi yang bertujuan untuk merekap dan mengelola data dan aplikasi yang dimaksud adalah aplikasi sistem administrasi penjualan. Aplikasi administrasi ini dibuat menggunakan bahasa pemograman PHP dan MYSQL dengan menggunakan metode waterfall. Aplikasi berbasis web ini bertujuan untuk memudahkan dan juga menghemat waktu pengguna dalam mengakses aplikasi tersebut sehingga sangat membantu pengguna dalam proses administrasi
\end{abstract}

Kata Kunci: Administrasi, Website, Komputer, Aplikasi.

\section{PENDAHULUAN}

Perkembangan teknologi yang semakin pesat menimbulkan suatu revolusi baru yang berupa peralihan sistem kerja yang konvensional ke era digital. Perubahan ini juga telah merubah cara pandang setiap orang dalam melakukan berbagai kegiatan salah satunya adalah dalam proses administrasi. Proses administrasi itu sendiri dapat dijalankan dengan suatu sistem informasi berbasis web.

Website ini didasari dari adanya perkembangan teknologi informasi dan komunikasi. Melalui perkembangan teknologi informasi, tercipta suatu jaringan antar komputer yang saling berkaitan. Jaringan yang dikenal dengan istilah internet secara terus-menerus menjadi pesan-pesan elektronik, termasuk email, transmisi file, dan komunikasi dua arah antar individu atau komputer.

Sehingga banyak seseorang yang memanfaatkan perkembangan teknologi untuk mempromosikan usahanya salah satu usaha yang sekarang ini semakin marak dan ber- kembang dengan sangat pesat adalah depot air minum isi ulang. Hampir disetiap tempat bisa ditemukan depot pengisian air minum isi ulang terutama di daerah perkotaan dan di daerah sekitar kampus.

Banyaknya depot air minum isi ulang ini memang bisa mengatasi masalah kebutuhan air minum untuk masyarakat luas, dan masih banyak depot air minum isi ulang yang masih menggunakan sistem administrasi penjualan nya dengan cara manual, seperti contohnya pada Toko Royalti.

Oleh karena alasan tersebut mendorong penulis untuk melakukan penelitian dengan judul: "Rancang Bangun Sistem Informasi Administrasi Berbasis Web Dengan Php Dan Mysql Pada Toko Royalti"

\section{LANDASAN TEORI \\ 1. Pengertian Sistem}

Definisi sistem berkembang sesuai dengan konteks dimana pengertian sistem itu digunakan. Secara sederhana sistem dapat di- 
artikan sebagai suatu kumpulan atau himpunan dari unsur atau variabel-variabel yang saling terorganisasi, saling interaksi dan bergantung satu sama lain. Definisi lain menurut Menurut Yakub (2012:1), Sistem adalah suatu jaringan kerja dari prosedurprosedur yang saling berhubungan, berkumpul bersama-sama untuk melakukan suatu kegiatan atau untuk tujuan tertentu.

Sedangkan menurut Sutarman (2012:22), Sistem adalah kumpulan yang saling berhubungan dan berinteraksi dalam satu kesatuan untuk menjalankan suatu proses pencapaian suatu tujuan utama.

\section{Pengertian Informasi}

Menurut McLeod (2012), informasi adalah data yang diolah menjadi bentuk lebih berguna dan lebih berarti bagi yang menerimanya.

Menurut Tata Sutabri (2012), informasi adalah data yang telah diklasifikasikan atau diolah atau diinterpretasikan untuk digunakan dalam proses pengambilan keputusan.

Menurut Amin (2012), informasi adalah data yang diolah menjadi bentuk yang lebih berguna dan lebih berarti bagi penerima dan digunakan untuk mengambil keputusan.

Berdasarkan pendapat yang dikemukan di atas dapat ditarik bahwa informasi adalah data yang sudah diolah, dibentuk atau dimanipulasi sesuai dengan keperluan tertentu bagi penggunanya.

\section{Metode Waterfall}

Menurut Pressman (2010) model waterfall adalah model klasik yang bersifat sistematis, berurutan dalam membangun software. Berikut ini ada dua gambaran dari waterfall model.

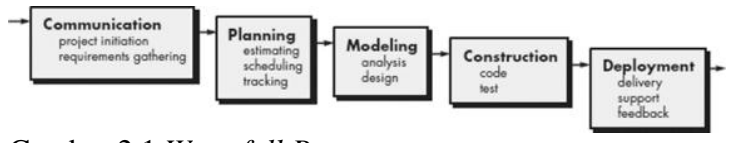

Gambar 2.1 Waterfall Pressman

Fase-fase dalam model waterfall menurut referensi Pressman:

\section{a. Communication}

Langkah ini merupakan analisis terhadap kebutuhan software, dan tahap untuk mengadakan pengumpulan data dengan melakukan pertemuan dengan customer, maupun mengumpulkan data-data tambahan baik yang ada di jurnal, artikel, maupun dari internet.

\section{b. Planning}

Proses planning merupakan lanjutan dari proses communication (analysis requirement). Tahapan ini akan menghasilkan dokumen user requirement atau bisa dikatakan sebagai data yang berhubungan dengan keinginan user dalam pembuatan software, termasuk rencana yang akan dilakukan.

c. Modeling

Proses modeling ini akan menerjemahkan syarat kebutuhan ke sebuah perancangan software yang dapat diperkirakan sebelum dibuat coding. Proses ini berfokus pada rancangan struktur data, arsitektur software, representasi interface, dan detail (algoritma) prosedural. Tahapan ini akan menghasilkan dokumen yang disebut software requirement.

\section{d. Construction}

Construction merupakan proses membuat kode. Coding atau pengkodean merupakan penerjemahan desain dalam bahasa yang bisa dikenali oleh komputer. Programmer akan menerjemahkan transaksi yang diminta oleh user. Tahapan inilah yang merupakan tahapan secara nyata dalam mengerjakan suatu software, artinya penggunaan komputer akan dimaksimalkan dalam tahapan ini. Setelah pengkodean selesai maka akan dilakukan testing terhadap sistem yang telah dibuat tadi. Tujuan testing adalah menemukan kesalahan-kesalahan terhadap sistem tersebut untuk kemudian bisa diperbaiki.

e. Deployment

Tahapan ini bisa dikatakan final dalam pembuatan sebuah software atau sistem. Setelah melakukan analisis, desain dan pengkodean maka sistem yang sudah jadi akan digunakan oleh user. Kemudian software yang telah dibuat harus dilakukan pemeliharaan secara berkala.

\section{Unified Modeling Language (UML)}

Menurut Nugroho (2010), UML (Unified Modeling Language) adalah bahasa pemodelan untuk sistem atau perangkat lunak yang berparadigma (berorientasi objek). Pemodelan (modeling) sesungguhnya digunakan untuk penyederhanaan permasalahan-permasalahan yang kompleks sedemikian rupa sehingga lebih mudah dipelajari dan dipahami.

Menurut Joomla (2014). Unified Modeling Language (UML) merupakan standard modeling language yang terdiri dari kumpulan-kumpulan diagram, dikembangkan untuk membantu para pengembang sistem dan 
software agar bisa menyelesaikan tugas-tugas seperti: Spesifikasi, Visualisasi, Desain Arsitektur, Konstruksi, Simulasi dan testing serta Dokumentasi.

\section{METODE PENELITIAN}

Pengumpulan data merupakan langkah yang penting dalam penelitian. Data yang terkumpul akan digunakan sebagai bahan analisis dan pengujian hipotesis yang telah dirumuskan. Pengumpulan data harus dilakukan dengan sistematis, terarah dan sesuai dengan masalah penelitian. Berikut ini adalah metode pengumpulan data yang penulis gunakan sebagai berikut:

\section{Observasi}

Observasi, pada tahapan ini diadakan kegiatan pengamatan mengenai struktur dan navigasi website yang akan dibangun, agar dapat menjadi website yang user friendly.

\section{Wawancara}

Wawancara, mencari data dengan cara melakukan tanya jawab pada pihak terkait, yang mempunyai wewenang atas data-data yang berhubungan dengan obyek penelitian.

\section{Dokumentasi}

Dokumentasi dilakukan dengan cara pengambilan data melalui dokumen tertulis maupun elektronik dari lembaga/institusi. Dokumen diperlukan untuk mendukung kelengkapan data yang lain. Maka peneliti telah mencatat dan mengambil beberapa data dari Toko Royalti.

\section{ANALISIS DAN PEMBAHASAN}

\section{Analisis Sistem yang Berjalan}

Analisis merupakan kegiatan untuk menguraikan sistem yang utuh kedalam bagian komponennya dengan maksud mengidentifikasi dan sekaligus mengevaluasi permasalahan atau hambatan yang ada pada sistem serta merencanakan kebutuhan dalam perbaikan sistem. Menganalisis terhadap sistem yang sedang berjalan dilakukan untuk mengetahui dan menentukan masalah yang sebenarnya pada sistem administrasi yang sudah ada.

Sistem administrasi di Toko Royalti saat ini masih belum optimal, karena masih dilakukan secara manual. Hal ini menyebabkan beberapa dokumen bisa hilang dan rusak. Analisis yang penulis lakukan ini terdiri dari analisis kebutuhan sistem dan evaluasi dari sistem yang sedang berjalan.
Analisis sistem adalah penguraian dari suatu sistem informasi yang utuh kedalam bagian komponen-komponennya dengan maksud mengidentifikasi dan mengevaluasi kekurangan-kekurangan yang terjadi dan kebutuhan-kebutuhan yang diharapkan sehingga dapat diusulkan perbaikan-perbaikannya.

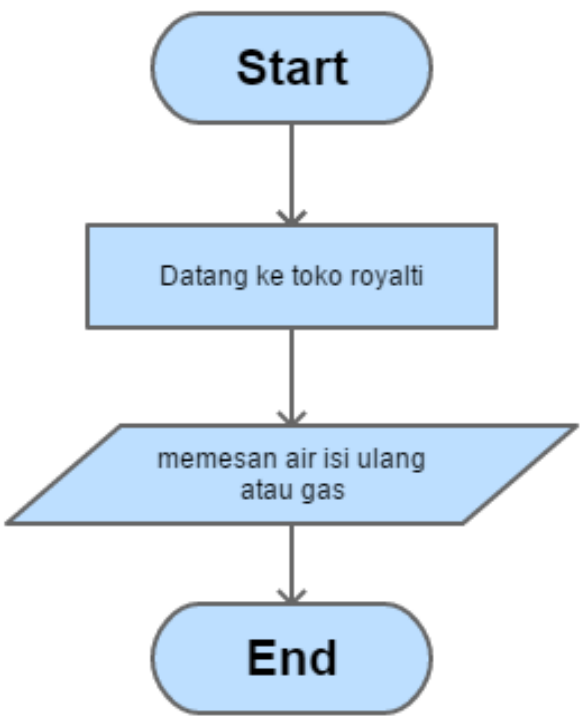

Gambar 4.1. Flowchart Diagram Pemesanan

\section{Gambaran Umum Sistem yang Diusul- kan}

Perancangan sistem dilakukan untuk memberikan gambaran umum tentang sistem yang dikembangkan atau yang diubah menjadi sistem aplikasi yang baru kepada pemakai atau user. Tahapan desain sistem mempunyai 2 maksud dan tujuan utama yaitu:

1. Untuk memenuhi kebutuhan pemakai sistem aplikasi.

2. Untuk memberikan gambaran yang jelas dan rancang bangun yang lengkap kepada programmer.

Tujuan kedua lebih ditekankan pada desain sistem yang terinci yaitu pembuatan rancang bangun yang jelas dan lengkap yang nantinya digambarkan untuk pembuatan program aplikasi. 


\section{Perancangan Sistem Usulan}

1) Use Case Diagram

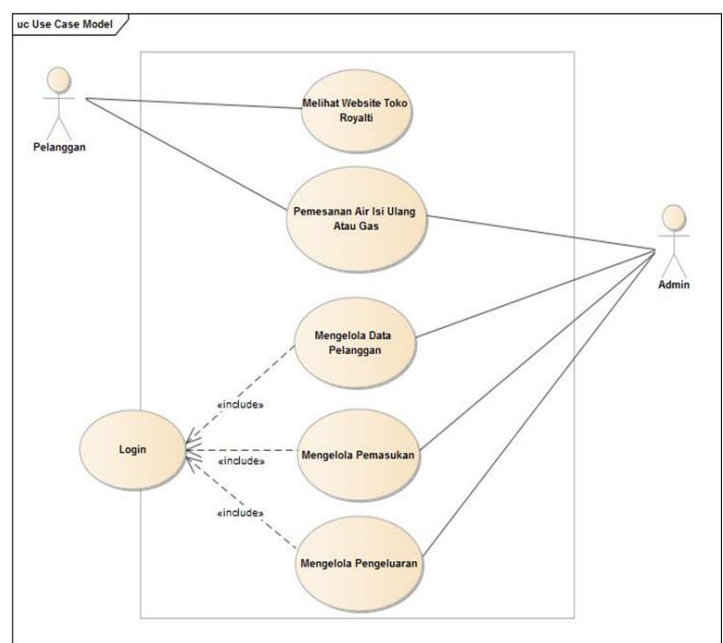

Gambar 4.2 Use Case Diagram Pemesanan

\section{2) Class Diagram}

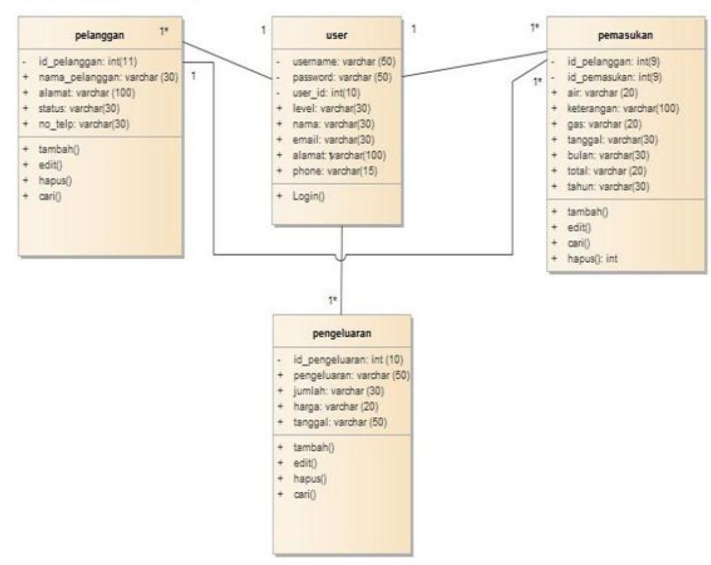

Gambar 4.3 Class Diagram Toko Royalti

\section{Rancangan Database}

Untuk rancangan database administrasi tabungan siswa sebagai berikut:

Tabel 4.1 Rancangan Database Tabel Admin

\begin{tabular}{|c|l|l|c|}
\hline No & \multicolumn{1}{|c|}{ Field } & \multicolumn{1}{c|}{ Type } & Value \\
\hline 1 & User_id & Int & 10 \\
\hline 2 & Username & Varchar & 20 \\
\hline 3 & Password & Varchar & 50 \\
\hline 4 & Nama & Varchar & 25 \\
\hline 5 & Email & Varchar & 20 \\
\hline 6 & Phone & Varchar & 15 \\
\hline 7 & Alamat & Varchar & 60 \\
\hline 8 & Level & Varchar & 10 \\
\hline
\end{tabular}

Tabel 4.2 Rancangan Database Tabel Pelanggan

\begin{tabular}{|c|l|l|c|}
\hline No & \multicolumn{1}{|c|}{ Field } & \multicolumn{1}{c|}{ Type } & Value \\
\hline 1 & Id_pelanggan & int & 10 \\
\hline 2 & Nama_pelanggan & varchar & 25 \\
\hline 3 & Alamat & varchar & 60 \\
\hline 4 & No_telp & varchar & 15 \\
\hline 5 & Status & varchar & 10 \\
\hline
\end{tabular}

Tabel 4.3 Rancangan Database Pemasukan

\begin{tabular}{|c|l|l|c|}
\hline No & \multicolumn{1}{|c|}{ Field } & \multicolumn{1}{c|}{ Type } & Value \\
\hline 1 & Id_pemasukan & int & 9 \\
\hline 2 & Id pelanggan & int & 9 \\
\hline 3 & Air & varchar & 10 \\
\hline 4 & Gas & varchar & 10 \\
\hline 5 & Total & varchar & 10 \\
\hline 6 & Keterangan & varchar & 30 \\
\hline 7 & Tanggal & Date Time & 15 \\
\hline 8 & Bulan & Date Time & 10 \\
\hline 9 & Tahun & Date Time & 10 \\
\hline
\end{tabular}

Tabel 4.4 Rancangan Database Tabel Setoran Pengeluaran

\begin{tabular}{|c|l|l|c|}
\hline No & \multicolumn{1}{|c|}{ Field } & \multicolumn{1}{|c|}{ Type } & Value \\
\hline 1 & Id_pengeluaran & Int & 10 \\
\hline 2 & Pengeluaran & Varchar & 15 \\
\hline 3 & Jumlah & Varchar & 10 \\
\hline 4 & Harga & Varchar & 10 \\
\hline 5 & Tanggal & Date Time & 15 \\
\hline
\end{tabular}

\section{Implementasi Sistem}

1) Interface Halaman Login

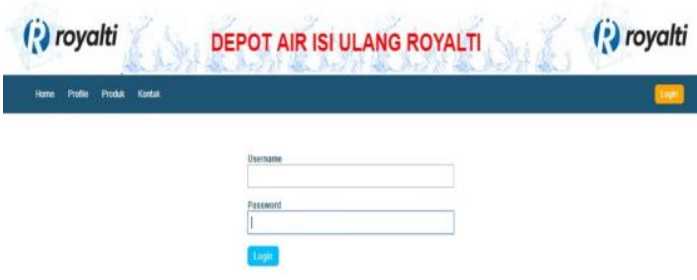

\section{Gambar 4.4 Halaman Login}

2) Interface Halaman Menu Utama

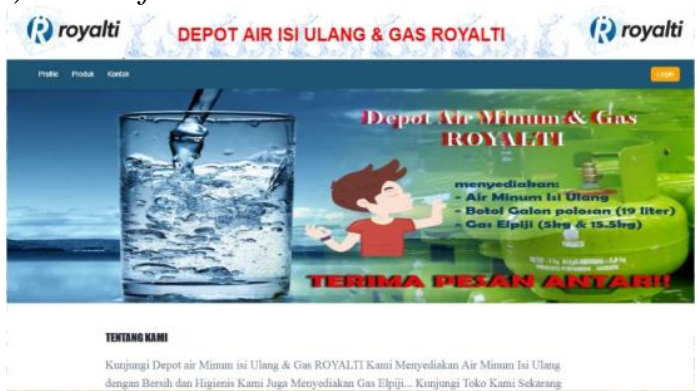

Gambar 4.5 Halaman Menu Utama 
3) Interface Halaman Pelanggan

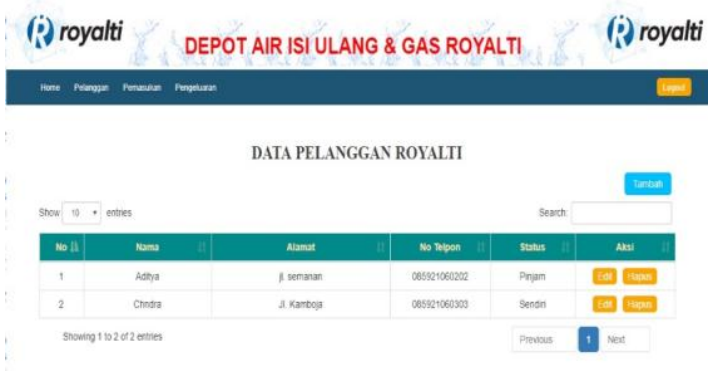

Gambar 4.6 Halaman Data Pelanggan

4) Interface Halaman Pemasukan

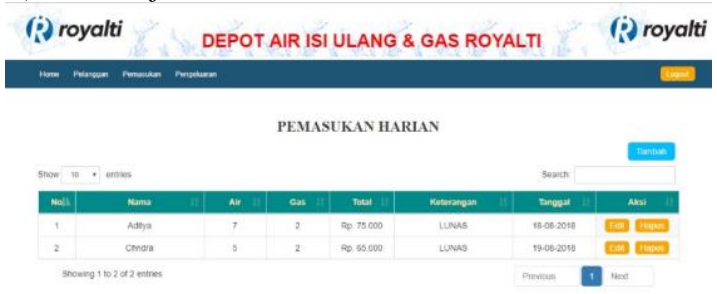

Gambar 4.7 Halaman Pemasukan

\section{5) Interface Halaman Pengeluaran}

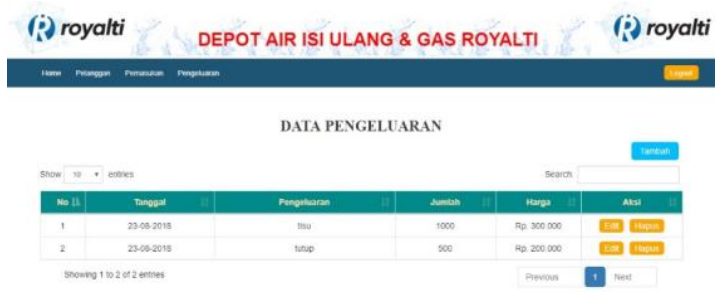

Gambar 4.8 Halaman Pengeluaran

\section{Pengujian Program}

Tahapan akhir dimana sistem yang baru diuji kemampuan dan keefektifannya sehingga didapatkan kekurangan dan kelemahan sistem yang kemudian dilakukan pengkajian ulang dan perbaikan terhadap aplikasi menjadi lebih baik dan sempurna. Pengujian program yang digunakan yaitu metode black box testing.
Tabel 4.6 Pengujian Black Box Testing

\begin{tabular}{|c|c|c|c|}
\hline No & Yang Dinji & Hasil yang Diinginkan & $\begin{array}{c}\text { Hasil yang } \\
\text { Didapat }\end{array}$ \\
\hline 1. & Login & $\begin{array}{l}\text { Ketika tombol login diklik maka akan } \\
\text { menampilkan form login. }\end{array}$ & Sesuai \\
\hline 2. & Form Login & $\begin{array}{l}\text { Ketika memasukan data username dan password } \\
\text { dengan benar maka akan masuk ke menu utama } \\
\text { admin. }\end{array}$ & Sesuai \\
\hline 3. & $\begin{array}{l}\text { Tombol } \\
\text { Pelanggan }\end{array}$ & $\begin{array}{l}\text { Ketika tombol diklik maka akan menampilkan } \\
\text { form data pelanggan. }\end{array}$ & Sesuai \\
\hline 4. & $\begin{array}{l}\text { Form } \\
\text { Pelanggan }\end{array}$ & $\begin{array}{l}\text { Ketika menambahkan data pelanggan maka data } \\
\text { akan disimpan dalam database. }\end{array}$ & Sesuai \\
\hline 5. & $\begin{array}{l}\text { Tombol } \\
\text { Pemasukan }\end{array}$ & $\begin{array}{l}\text { Ketika tombol diklik maka akan menampilkan } \\
\text { form data pemasukan. }\end{array}$ & Sesuai \\
\hline 6. & $\begin{array}{l}\text { Form } \\
\text { Pemasukan }\end{array}$ & $\begin{array}{l}\text { Ketika menambahkan data pemasukan maka } \\
\text { data akan disimpan dalam database. }\end{array}$ & Sesuai \\
\hline 7. & $\begin{array}{l}\text { Tombol } \\
\text { Pengeluaran }\end{array}$ & $\begin{array}{l}\text { Ketika tombol diklik maka akan menampilkan } \\
\text { form data pengeluaran. }\end{array}$ & Sesuai \\
\hline 8. & $\begin{array}{l}\text { Form } \\
\text { Pengeluaran }\end{array}$ & $\begin{array}{l}\text { Ketika menambahkan data pengeluaran maka } \\
\text { data akan disimpan dalam database. }\end{array}$ & Sesuai \\
\hline 9. & Tombol Home & $\begin{array}{l}\text { Ketika tombol home diklik akan menampilkan } \\
\text { grafik persentase. }\end{array}$ & Sesuai \\
\hline 10. & $\begin{array}{l}\text { Tombol } \\
\text { Produk }\end{array}$ & $\begin{array}{l}\text { Ketika tombol produk diklik maka akan } \\
\text { menampilkan form produk. }\end{array}$ & Sesuai \\
\hline & $\begin{array}{l}\text { Tombol } \\
\text { Kontak }\end{array}$ & $\begin{array}{l}\text { Ketika tombol kontak diklik maka akan } \\
\text { menampilkan form kontak. }\end{array}$ & Sesuai \\
\hline 12. & Tombol Profil & $\begin{array}{l}\text { Ketika tombol profil diklik maka akan } \\
\text { menampilkan form profil. }\end{array}$ & Sesuai \\
\hline 13. & $\begin{array}{l}\text { Tombol } \\
\text { Tambah }\end{array}$ & $\begin{array}{l}\text { Ketika tombol tambah diklik maka akan } \\
\text { menambahkan data. }\end{array}$ & Sesuai \\
\hline 14. & Tombol Edit & $\begin{array}{l}\text { Ketika tombol edit diklik maka akan mengubah } \\
\text { data. }\end{array}$ & Sesuai \\
\hline 15. & Tombol Hapus & $\begin{array}{l}\text { Ketika tombol hapus diklik maka akan } \\
\text { menghapus data. }\end{array}$ & Sesuai \\
\hline 16. & $\begin{array}{l}\text { Tombol } \\
\text { pencarian }\end{array}$ & $\begin{array}{l}\text { Ketika tombol pencarian diklik maka akan } \\
\text { menampilkan data yang dicari. }\end{array}$ & Sesuai \\
\hline
\end{tabular}

\section{KESIMPULAN}

Berdasarkan uraian dari proses analisa maka dapat disimpulkan sebagai berikut: Sistem informasi administrasi penjualan di Toko Royalti yang saat ini masih berjalan secara manual, jadi diperlukannya system aplikasi administrasi penjualan sesuai perkembangan teknologi yaitu berbasis web. Sistem ini dapat digunakan sebagai alat bantu administrasi di Toko Royalti

Untuk pelaksanaan kegiatan diharapkan adanya petugas admin yang bertanggung jawab mengenai pemakaian komputer yang berisi data-data penting di Toko Royalti. Melakukan perawatan terhadap sistem yang di bangun, seperti memasang anti virus di komputer admin, membackup database setiap enam bulan sekali, lakukan defragment setidaknya satu bulan sekali, dan sisakan sedikit space kosong di partisi tempat sistem operasi berada

\section{DAFTAR PUSTAKA}

Arief M Rudianto. (2011). Pemrograman Web Dinamis menggunakan PHP dan $M y S Q L$. Yogyakarta: Andi Offset.

Jogiyanto Bukunya Yakub. 2012. Pengantar Sistem Informasi. Graha Ilmu

Jogiyanto, Hartono. (2010). Analisis dan Desain Sistem Informasi. Edisi III. Yogyakarta: ANDI. 
Joomla (2014) dari http://soetrasoft.com:2014.

Maimunah, Lusyani Sunarya, dan Nina Larasati. 2012. Media Company Profile Sebagai Penunjang Informasi dan Promosi. Jurnal CCIT Vol-5 No.3. (Mei 2012)

Minartiningtyas. (2013). Dari http://informatika.web.id/data-informasisistem-informasi.htm\#more-1974.
Nugroho, Adi. (2010). Rekayasa Perangkat Lunak Berorientasi Objek dengan Metode USDP. Yogyakarta: Andi Offset.

Raymond, McLeod. (2012). Pengantar Sistem Informasi. Yogyakarta.

Sutabri, Tata. (2012). Konsep Sistem Informasi. Yogyakarta: Andi Offset.

Sutarman. (2012). Buku Pengantar Teknologi Informasi. Jakarta: Bumi Aksara. 